\title{
Development of Coal Mine Filling Paste with Certain Early Strength and Its Flow Characteristics
}

\author{
Feng Zhang $\mathbb{D}^{1},{ }^{1}$ Jinxiao Liu $\mathbb{D},{ }^{1,2,3}$ Haiming Ni $\mathbb{D}^{4},{ }^{4}$ Wenxin $\mathrm{Li} \mathbb{D},{ }^{1,2}$ and Yongle Liu $\mathbb{D}^{1}$ \\ ${ }^{1}$ College of Energy and Mining Engineering, Shandong University of Science and Technology, 579 Qianwangang Rd., \\ Huangdao District, Qingdao 266590, China \\ ${ }^{2}$ Mine Disaster Prevention and Control-Ministry of State Key Laboratory Breeding Base, Shandong University of Science \\ and Technology, 579 Qianwangang Rd., Huangdao District, Qingdao 266590, China \\ ${ }^{3}$ State Key Laboratory of Mining Disaster Prevention and Control Co-founded by Shandong Province and the Ministry of Science \\ and Technology, National Engineering Laboratory for Backfill Coal Mining, Shandong University of Science and Technology, \\ Qingdao 266590, Taian 271000, China \\ ${ }^{4}$ College of Environment and Safety Engineering, Shandong University of Science and Technology, 579 Qianwangang Rd., \\ Huangdao District, Qingdao 266590, China
}

Correspondence should be addressed to Jinxiao Liu; skd993938@sdust.edu.cn

Received 15 December 2020; Revised 25 December 2020; Accepted 13 January 2021; Published 31 January 2021

Academic Editor: Bin Gong

Copyright (c) 2021 Feng Zhang et al. This is an open access article distributed under the Creative Commons Attribution License, which permits unrestricted use, distribution, and reproduction in any medium, provided the original work is properly cited.

In coal mine paste filling technology, geomaterials like coal gangue and fly ash are used as the main component, and cement is applied as the cementing material. In the mining production, mining-and-filling is a cyclic work, where the filling immediately after mining and mining immediately after filling. Long solidification time after filling will affect mining; consequently, the paste should have early strength. In addition, the prepared paste will be conveyed to goaf through the pipeline. The paste flow characteristics will change to some extent in the conveying process, and there is uncertainty about whether the paste can meet the requirements of pumpability and strength. Therefore, the influence of pipeline conveying on flow characteristics of paste before filling the goaf should be taken into consideration. Based on the above two points, this paper studies the paste strength, backfill strength, and pumpability parameters in coal mine paste filling and determines the early and later strength of coal mine paste, as well as the pumpability parameters such as slump degree, segregation degree, setting time, and paste gradation. With the determined mass proportion of coal gangue, fly ash, and silicate cement, the orthogonal test was carried out with three factors including gypsum content, the content of early strength agent $\left(\mathrm{Na}_{2} \mathrm{SO}_{4}\right)$, and the mass concentration, and at three levels. The factors affecting paste flow characteristics were determined by range analysis, and the factors affecting the paste's early strength were determined by the XRD test and SEM test on its microstructure. With paste proportioning and pipeline conveying simulation system, taking slump, segregation degree, backfill strength, and other parameters as indicators, we obtain the influence law of pipeline conveying on the flow characteristics of paste. The research has great theoretical and practical significance for developing coal paste with early strength and its flow characteristics.

\section{Introduction}

Backfilling was born to meet the needs of the mining industry, and it has a history of more than one hundred years. Firstly, the engineering practice of filling emerged in the 1930s, in noncoal mining [1-3]. According to the development history and characteristics of filling materials, the mine filling technology has experienced a change from noncementing fill- ing to cementing one [4-7]. Later in the 1980s and 1990s, new technologies such as high-concentration filling [8-13], paste filling [14-17], waste cementing filling [18-22], and total tailing cementing filling [23-25] were developed as the original filling process, which were costly and not environmentally friendly. Since then, with the successful application of various new filling technologies and cementing materials, the further-developed paste and paste pumping cementing 
filling technology has greatly boosted the development of backfilling mining technology [26-28].

Compared with other filling materials, the paste material has unique characteristics. First, the concentration of paste filling material is higher, reaching $76 \% \sim 84 \%$. Second, the slurry in the paste filling material is free from precipitation, segregation, and bleeding, which is conducive to the drainage work of the filling face. It also avoids the loss of large amounts of solid particles during drainage. At the same time, the flow state of the paste filling material is plunger flow, and the slurry on the cross-section of the filling pipe flows at the same rate, making it convenient for pipeline conveying. Then, the compression ratio of paste filling material is extremely low, generally only about $1 \%$. It is mainly due to the fact that the voids between solid particles in paste filling material are filled with cementing materials and water, making it difficult to be compressed, which is good for controlling the mining subsidence [29-31].

With the growth of China's coal production in recent years, coupled with the uneven distribution of coal resources, poor geological mining conditions, and dense population, most of the coal resources in eastern China are nearly exhausted, and most of them are unexploited coal under "three circumstance," that is, the coal mines under buildings, water, and railways. In addition, coal mines discharge large amounts of solid wastes such as coal gangue and fly ash to the ground, which not only occupies land but also pollutes the environment. Considering the problems above, many coal mines such as Taiping Coal Mine, Xingtai coal Mine, and Tangkou coal mine in Shandong Province, China, are beginning to use solid wastes like coal gangue and fly ash to prepare the paste and then backfill to goaf, which has achieved good results [32-35].

Paste filling in coal mines differs from that in metal mines. First, the filling materials are composed of solid wastes such as crushed gangue and fly ash. The composition and gradation of the filling materials are quite complicated. Second, considering the relationship between filling and coal extracting, the paste should have early strength. In addition, the composition and lumpiness of coal mine paste filling materials are relatively complicated, making the paste characteristics uncertain. Segregation and condensation occurring during conveying will block the pipeline. The paste solidifying in the pipeline will cause great trouble to coal mine filling. In view of the problems above and researches on paste filling and its materials [36-42], it is concluded that the specific parameter requirements for the strength and pumpability should be obtained first. Then, with coal gangue, fly ash, silicate cement, early strength agent, etc., the paste that has certain early strength characteristics and meets the requirements of coal mine filling is developed. Finally, the pipeline conveying test should be done on the developed paste to verify its pumpability and the stability of characteristics [43-58].

\section{Typical Paste Filling Process System of Coal Mine}

In this paper, the authors take the paste filling system of Daizhuang Coal Mine in Shandong Province, China, as an example. In this case, the paste filling system for the longwall working face is introduced. The raw material for paste filling include gangue, fly ash, cementing material, and water. Before filling, coal gangue first undergoes two-stage crushing, and then, coal gangue, fly ash, cementing materials, and water are mixed in a certain proportion to prepare the paste. Then, the paste is transported to the goaf by pumping. In terms of the process flow, it mainly includes gangue crushing, proportioning and mixing, pipeline pumping, and filling working face, as shown in Figure 1.

2.1. Gangue Crushing. Crushing coal gangue adopts twostage crushing and one-stage screening, which mainly consists of three steps. Step 1: Primarily crush the coal gangue with a jaw crusher, with a particle size of 75 100 mm. Step 2: Screen the crushed coal gangue with a vibrating screen. The part smaller than $25 \mathrm{~mm}$ goes directly to the gangue silo via the conveyor, and the coal gangue larger than $25 \mathrm{~mm}$ is crushed for a second time. Step 3: Break the larger gangue into fine particles smaller than $25 \mathrm{~mm}$ and then send to the gangue silo.

2.2. Proportioning and Mixing. The paste proportioning and mixing has three steps. First, coal gangue, fly ash, cementing materials, and water in the storage silo are automatically weighed and put into the mixer. The water is supplied from the tank with a weighing hopper by the water pump. Then, the paste is thoroughly mixed for 50 seconds. Finally, open the outlet of the mixer and pour the mixed paste into the grouting port of the filling pump.

2.3. Pipeline Pumping. The mixed paste enters the grouting port of the filling pump by its own weight and then is pumped into the pipe. The paste is sent into the mine by pumping through the filling hole near the filling station and then transported to the filling working face along the pipe.

2.4. Filling Working Face. After the paste enters the working face, three points are necessary to ensure the paste to get into the filling space quickly. First, the temporary support in the filling space guarantees the stability of the overburden before and during the filling. Therefore, the backfill should have certain strength during this period. Second, the isolation baffle should be set up as soon as possible to form a closed filling space. Third, the filling sequence should be arranged reasonably to ensure the smooth operation of filling.

\section{Analysis on Strength of Backfill and Pumpability of Paste in Coal Mine}

3.1. Strength Analysis of Paste Backfill. Considering the relationship between the backfill and the overburden, there are two types of backfill strength: early strength and later strength.

3.1.1. Early Strength. The early strength of the backfill mainly refers to its intensity from the time when the paste enters the enclosed space behind the work face support to the time when the filling support moves forward. During this period, the backfill itself is able to maintain self-supporting strength. The time should not be too long, usually 16 hours or so; 


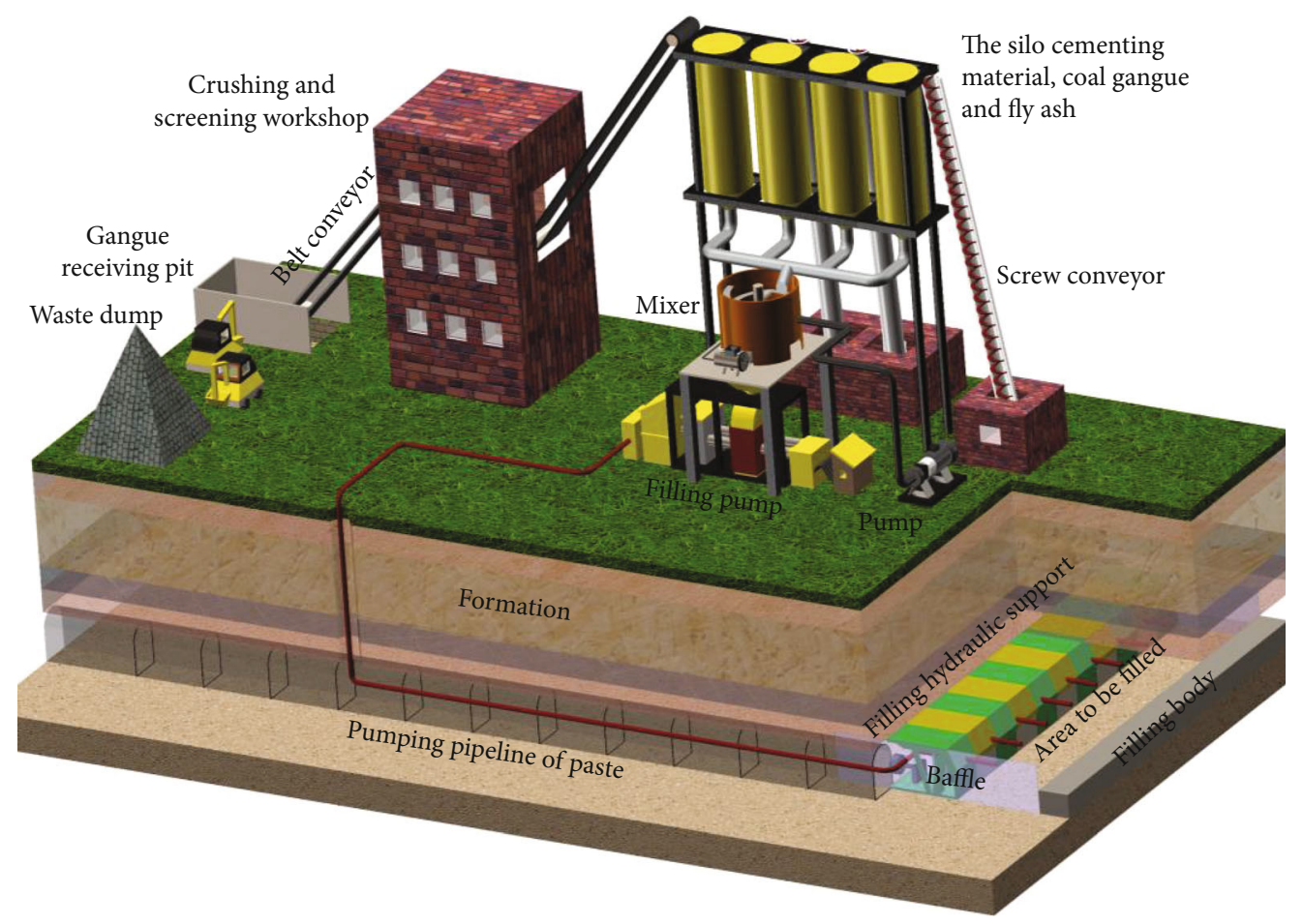

Figure 1: Coal mine paste filling process.

otherwise, it will affect normal production. Therefore, when preparing the paste, the self-supporting strength and curing time of the paste should be designed.

Many formulas are used to calculate the backfill selfsupporting strength, such as empirical formula, Thomas model, and Lu Ping modified model [59-61]. See Eq. (1) for the empirical formula method. Thomas analyzed the stability of the three-dimensional wedge model of the backfill in 1979 and derived a method to determine the self-supporting strength of cemented backfill, as shown in Eq. (2). The Thomas model only considers the geometry size of the backfill and the bulk density of filling materials and ignores the strength of filling materials. Therefore, Lu Ping proposed a modified model based on Thomas's in 1987, see Eq. (3)

$$
\sigma_{c}=\sqrt[3]{\frac{h^{2}}{a}}
$$

where $\sigma_{c}$ is the self-supporting strength, $\mathrm{MPa} ; h$ represents the height of cemented backfill, $\mathrm{m}$; and $a$ indicates empirical coefficient. Since the mining height of the coal seam is low, it usually takes 6000 .

$$
\sigma_{c}=\frac{\gamma \cdot h}{1+h / l},
$$

where $\gamma$ denotes the bulk density of cemented backfill, $\mathrm{MN} / \mathrm{m}^{3}$; and $l$ shows the width of backfill, $\mathrm{m}$.

$$
\sigma_{c}=\frac{\gamma \cdot h}{(1-k)\left[\operatorname{tg} \alpha+(2 h / 1) \cdot\left(c_{1} / c\right) \cdot \sin \alpha\right]},
$$

where $k$ is lateral pressure coefficient, $k=1-\sin \varphi_{1}, \alpha=45^{\circ}$ $+\varphi / 2$; and $c_{1}, \varphi_{1}$ represent cohesion and friction angle between backfill and surrounding rock; $c, \varphi$ are cohesion and friction angle of backfill. $c=c_{1}=0.2 \mathrm{MPa}$ and $\varphi_{1}=\varphi=$ $41^{\circ}$ are suitable for the backfill in the goaf of the coal mine.

Each equation is only valid under certain assumptions. The comparison of the self-supporting strength of backfill obtained by the above three equations is shown in Figure 2 . Obviously, the self-supporting strength calculated by the empirical equation is much higher than those by Thomas model and Lu Ping modified model. In the process of coal mine filling, in order to make sure that the designed strength of the backfill has a high safety factor, the authors chose the one calculated by the empirical equation, type (1), as the self-supporting strength of coal mine backfill.

Through the analysis of self-supporting strength of multiple coal mines, it is concluded that the early self-supporting strength of the backfill should be between $0.10 \mathrm{MPa}$ and $0.16 \mathrm{MPa}$, that is, the strength of mixed paste should reach $0.10 \sim 0.16 \mathrm{MPa}$ in 16 hours.

3.1.2. Later Strength. As the removal of the isolation baffle and advancement of working face, the overburden begins to sink and exert a force on the backfill. When the overburden movement stopped completely, the past reaches its later strength. This period ranges from several months to several years, during which the strength of the backfill should be greater than the load imposed by the overburden. In the process of paste filling, the simplest and most effective way is to control the overburden movement by completely filling the goaf with backfill after coal extraction, that is, the full mining and full-filling method. In this method, the backfill is always 


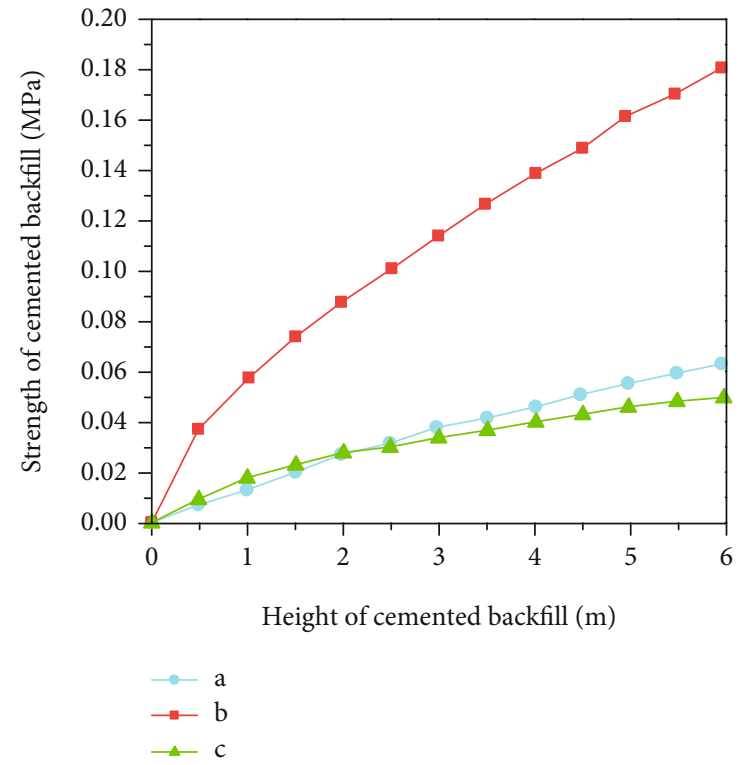

FIGURE 2: Comparison of self-supporting strength of cement. (a) Empirical equation. (b) Lu Ping modified model. (c) Thomas model.

in a triaxial stress state due to the joint force of the roof, floor, and surrounding rocks. Therefore, the Coulomb-Mohr strength criterion can be adopted to design the later strength of the backfill. Practice has shown that the backfill can meet the requirements of mine filling when its later strength reaches $1 \sim 1.5 \mathrm{MPa}$.

3.2. Analysis on the Pumpability of Coal Mine Paste. To pass the pipeline smoothly, the paste needs to meet some conditions, and the pumpability is a comprehensive index of paste conveying. This indicator manifests the fluidity, plasticity, stability, and the flow state of the paste during the pumping process. The pumpability can be analyzed and determined with parameters such as slump, segregation degree, setting time, and paste material gradation.

3.2.1. Slump. It is simple and intuitive to use a slump to indicate the fluidity of paste slurry. The slump of the paste refers to the depth of the final collapse due to the paste's own weight and internal resistance. The slump reflects the yield stress of the paste and is certainly related to yield stress. The slump of the pumpable paste should vary within a certain range. If the slump is too great, the paste will bleed too much, and if the slump is too low, the required pumping pressure will be too high, which will damage the equipment or make it impossible to pump. Field practice has proved that the slump of coal mine paste should not be less than $18 \mathrm{~cm}$.

3.2.2. Segregation Degree. The segregation of the paste is due to the relative movement between the solid particles in the filling material, which results in the uneven distribution of solid particles on the vertical section. Theoretically, if the paste does not segregate, its segregation degree is zero. However, in practice, due to various reasons, the segregation degree of the prepared paste is often greater than zero. Experience has proved that, as long as its segregation degree is less than $2 \mathrm{~cm}$, the paste can meet the requirements of longdistance conveying. Even if the paste stays in the pipeline for a period of time, the filling pump can be smoothly restarted for conveying.

3.2.3. Setting Time. Similar to pure cement paste, coal mine paste has an initial setting state and final setting state, corresponding to the initial setting time and final setting time. The length of setting time directly affects the normal production of the coal mine. Short setting time will hinder the mixing and conveying of the paste. Even before reaching the filling stope, the paste has already solidified, which will block the filling pipeline and interrupt the filling work. When the setting time is too long, the slurry does not solidify in a long time after entering the goaf, which not only cannot provide support for the roof but also increases the roof sinkage. This will affect both the progress of coal mining and the control of overburden subsidence. Therefore, the setting time of the paste should be measured before filling. Coal mine paste filling projects generally require a paste initial setting time of $3 \sim 4$ hours and a final setting time of $4 \sim 5$ hours.

3.2.4. Gradation of the Paste. There should be enough finegrained and ultra-fine-grained particles in paste materials. The fine-grained particles fill the gap between coarse particles. The ultra-fine-grained ones have a high specific surface area and water retention. After being combined with water molecules, they are distributed between coarse particles, thus ensuring the workability of the paste and the stability of the structure plane, so that the paste is malleable enough to maintain its three-dimensional structure when it is static. The results of domestic and foreign experiments show that the content of ingredients with a particle size less than $20 \mu \mathrm{m}$ must be greater than $15 \%$. The common method is to add fly ash to the filling material.

In terms of its type, nature, and particle size, the coarse and fine aggregates filled in mines are different from that of concrete. At present, there is no uniform specification and standard for the coarse and fine aggregate of mine paste. Practices show that the content of ultrafine particles with a particle size of less than $20 \mu \mathrm{m}$ in the paste should be kept in the range of $20 \% \sim 35 \%$, the content of coal gangue with a particle size of less than $5 \mathrm{~mm}$ should be kept within the range of $35 \% \sim 45 \%$, and the ratio of the maximum particle size of the aggregates to the diameter of conveying pipe should be less than $1: 5$.

\section{The Proportion Test of Coal Mine Paste}

4.1. Analysis on the Raw Materials for Paste Filling. A large number of materials are needed to fill the goafs of the coal mine. Paste filling can only be carried out when there are a lot of materials in or around the coal mine. If the coal mine has waste dumps, the gangue can be used as the coarse aggregate of paste. If there are many pebbles, construction wastes, and other materials around the coal mine, these can also be used as coarse aggregates. In the test, coal gangue, fly ash, and silicate cement are applied as the main materials, as shown in Figure 3. 


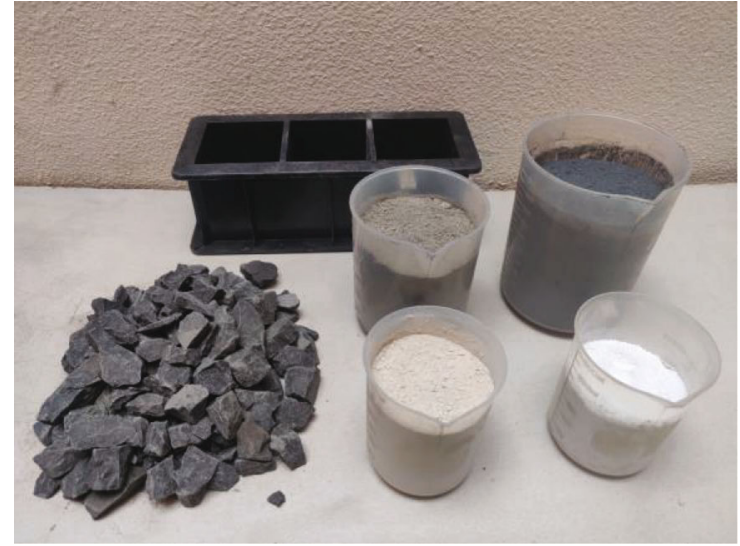

FIGURE 3: Raw materials.

In raw materials, coal gangue mainly acts as coarse aggregate and does not participate in the chemical reaction. However, the physical properties of coal gangue, such as particle size distribution, harmful impurities, and strength, have a great impact on the mechanical and physical properties of the paste.

The coal gangue in this test was taken from the Daizhuang coal mine of Shandong Zibo Mining Group. The majority of the coal gangue has a particle size of less than $100 \sim 250 \mathrm{~mm}$, and less have a particle size of $600 \mathrm{~mm}$. The average particle size is greater than $25 \mathrm{~mm}$ accounting for $13 \%$, particles with the size of $5 \sim 25 \mathrm{~mm}$ accounted for $57.9 \%$, and the part smaller than $5 \mathrm{~mm}$ accounted for $29.1 \%$. According to the requirements of paste gradation, the coal gangue was crushed in the test process. In the test, the maximum particle size of coal gangue is controlled within $25 \mathrm{~mm}$, and the screening results are shown in Figure 4.

Fly ash and other filling materials complement each other in paste filling. Before the paste solidifies, the fly ash and the cementing material play the role of microaggregate, which fills the gaps between the particles and gives the paste a good gradation. Moreover, due to the large surface area, the microaggregate has sufficient water retention. After combined with water molecules, the microaggregates increase the fluidity of the paste. During the hardening period of the paste, the hydration reaction occurs after the fly ash is mixed with the cementing material, which plays a role in gelation, but has no effect on paste early strength.

This test adopted the fly ash from the Qingdao power plant. The pulverized coal combustion of this plant has a high combustion ratio. The carbon content in the fly ash is relatively low with a density of $2.24 \mathrm{t} / \mathrm{m}^{3}$ and bulk density of $0.65 \mathrm{t} / \mathrm{m}^{3}$. The particle size distribution of fly ash after the screening is shown in Figure 5.

NO. 42.5 silicate cement produced by Shandong Shanshui Cement Group Co., Ltd., is used as cementing material in the test. The chemical and mineral composition of the clinker are shown in Table 1.

To ensure that the paste has a certain early strength, sodium sulfate and gypsum are added to the paste to accelerate the early setting and improve its early strength. Gypsum is a calcined building material, and its chemical composition is shown in Table 2.

4.2. Test Scheme and Results. An orthogonal test was carried out to prepare the paste with certain early strength. In view of the fact that there are too many factors affecting the paste characteristics, according to the grading principle of coal mine paste and the previous experience of paste proportion [62-65], the mass proportion of silicate cement, fly ash, and coal gangue was set as $1: 3: 6$. The gypsum content was taken as factor $\mathrm{A}$, sodium sulfate content as factor $\mathrm{B}$, and paste mass concentration as factor $\mathrm{C}$, which are determined as three levels. The three levels of factor A were $1 \%, 2 \%, 3 \%$, respectively; the levels of factor $\mathrm{B}$ were $0.2 \%, 0.4 \%, 0.6 \%$, respectively; and the levels of factor $\mathrm{C}$ were $79 \%, 82 \%$ and $85 \%$, respectively.

First, the silicate cement, gypsum, and sodium sulfate were weighed and dry mixed for 3 minutes. Second, coal gangue and fly ash were weighed and dry mixed for 3 minutes, which then was mixed with the water specified in the test for 2 minutes. The slump, segregation degree, initial setting time, and final setting time of paste shall be measured immediately after the slurry is discharged from the mixer, as shown in Figure 6 . The paste was put into a $70.7 \mathrm{~mm} \times$ $70.7 \mathrm{~mm} \times 70.7 \mathrm{~mm}$ test mold which was finally put into the standard curing box. When the paste was cured to the test age, its uniaxial compressive strength was tested. Three specimens were tested at different curing ages of each proportion, and the average strength value was taken. The results of the orthogonal test and paste parameter test are shown in Table 3.

4.3. Analysis of Test Results. The range analysis was conducted on the test results. The analysis considered five test indicators including 16-hour and 28-day uniaxial compressive strength at each age, initial setting time, slump, and segregation degree. The results show that the mass concentration has the greatest influence on the slump and segregation; sodium sulfate, the early strength agent, has the greatest influence on the initial setting, the strength of 16-hour and 28-day paste, followed by gypsum. It can be concluded from the test results that the higher the early strength of the paste, the lower the 28-day strength.

According to the needed coal mine filling paste strength and pumpability parameters, the ratio of P6 and P9 meets the requirements. There is little difference between P6 and P9 intensity at 16 hours and 28 days. In terms of initial setting time and segregation degree, P6 is close to the limit value, while the various test indicators of $\mathrm{P} 9$ are more reasonable. Therefore, the optimal ratio of the orthogonal test is P9.

\subsection{Analysis on the Early Microstructure and Hydration} Process of Paste. When preparing the paste, a certain amount of cementing material is needed. Once the cementing material is mixed with water, a series of physical and chemical reactions will occur. The slurry of cementing material gradually loses its fluidity and becomes a hardened body with a certain strength, which is called the hydration and hardening process of the cement. The mechanical property of the 


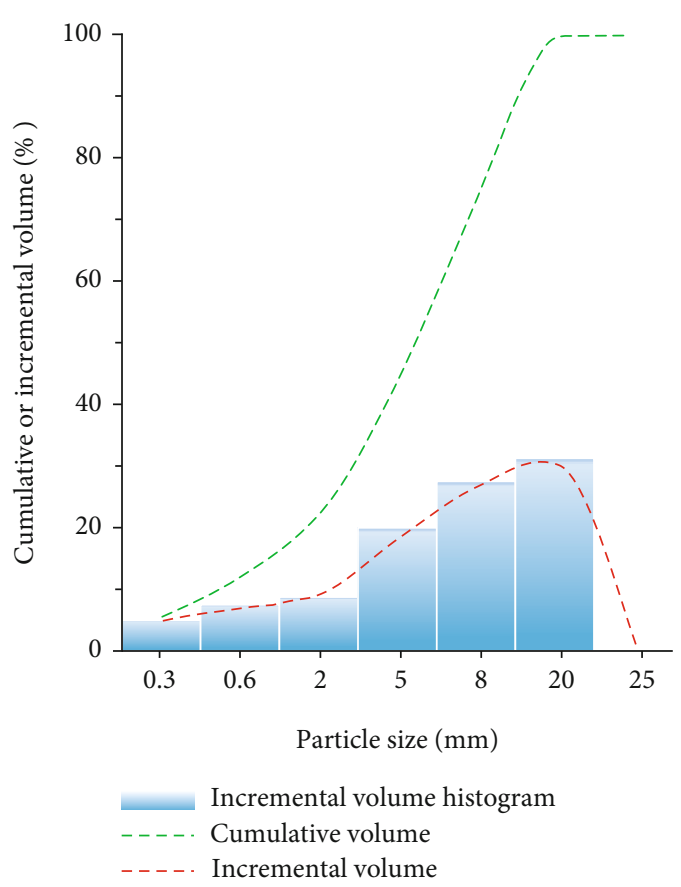

FIGURE 4: Distribution of the size of crushed coal gangue particle.

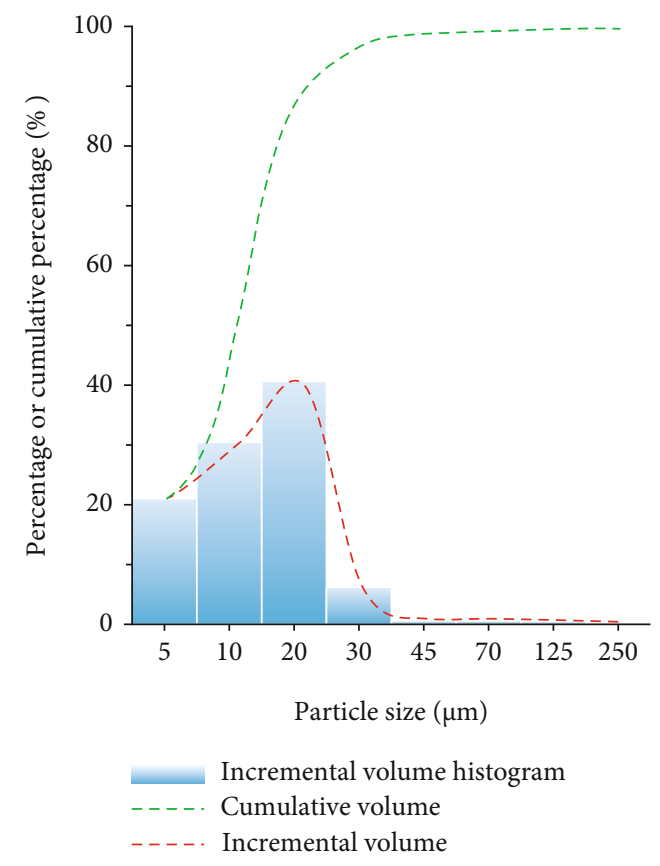

Figure 5: Fly ash size distribution.

hardened body is closely related to the hydration products and microstructure, which are constantly changing with the hydration process. Therefore, the early strength of paste can be studied from the hydration products and microstructure of paste cementing materials. In this test, the P9 test scheme was chosen to prepare the paste. The samples were made according to the standard consistency and cured in the standard curing box for 16 hours, and then, the prepared paste test blocks were put into the X' Pert PRO MPD diffractometer and Apreo high-resolution scanning electron microscope for X-ray diffraction test and SEM test. Finally, the microstructure and hydration products were analyzed.

Paste cementing material consists of silicate cement, sodium sulfate, and gypsum, so its cementing components include $2 \mathrm{CaO} \cdot \mathrm{SiO}_{2}, 3 \mathrm{CaO} \cdot \mathrm{SiO}_{2}, 3 \mathrm{CaO} \cdot \mathrm{SiO}_{2}, 3 \mathrm{CaO} \cdot \mathrm{Al}_{2} \mathrm{O}_{3}$, $4 \mathrm{CaO} \cdot \mathrm{Al}_{2} \mathrm{O}_{3} \cdot \mathrm{Fe}_{2} \mathrm{O}_{3}, \mathrm{Na}_{2} \cdot \mathrm{SO}_{4}, \mathrm{CaSO}_{4} \cdot 2 \mathrm{H}_{2} \mathrm{O}$, and $\mathrm{SiO}_{2}$. Gypsum allows the reaction speed of $3 \mathrm{CaO} \cdot \mathrm{Al}_{2} \mathrm{O}_{3}$ and $3 \mathrm{CaO} \cdot \mathrm{SiO}_{2}$ in silicate cement faster than that of $2 \mathrm{CaO} \cdot \mathrm{SiO}_{2}$ and $4 \mathrm{CaO} \cdot \mathrm{A}-$ $\mathrm{l}_{2} \mathrm{O}_{3} \cdot \mathrm{Fe}_{2} \mathrm{O}_{3}$, and $\mathrm{Na}_{2} \cdot \mathrm{SO}_{4}$ plays a role of hydration material. Therefore, after adding water, $3 \mathrm{CaO} \cdot 3 \mathrm{Al}_{2} \mathrm{O}_{3} \cdot \mathrm{CaSO}_{4}$, $3 \mathrm{CaO} \cdot \mathrm{Al}_{2} \mathrm{O}_{3}$, and $3 \mathrm{CaO} \cdot \mathrm{SiO}_{2}$ are the first to react. The reaction process is as follows:

$$
\begin{gathered}
2\left(3 \mathrm{CaO} \cdot \mathrm{SiO}_{2}\right)+11 \mathrm{H}_{2} \mathrm{O}=3 \mathrm{CaO} \cdot 2 \mathrm{SiO}_{2} \cdot 8 \mathrm{H}_{2} \mathrm{O}+3 \mathrm{Ca}(\mathrm{OH})_{2} \\
\mathrm{Na}_{2} \cdot \mathrm{SO}_{4}+\mathrm{Ca}(\mathrm{OH})_{2}+2 \mathrm{H}_{2} \mathrm{O}=\mathrm{CaSO}_{4} \cdot 2 \mathrm{H}_{2} \mathrm{O}+2 \mathrm{Na} \cdot \mathrm{OH} \\
3 \mathrm{CaO} \cdot \mathrm{Al}_{2} \mathrm{O}_{3}+3 \mathrm{CaSO}_{4} \cdot 2 \mathrm{H}_{2} \mathrm{O}+26 \mathrm{H}_{2} \mathrm{O}=3 \mathrm{CaO} \cdot \mathrm{Al}_{2} \mathrm{O}_{3} \cdot 3 \mathrm{CaSO}_{4} \cdot 32 \mathrm{H}_{2} \mathrm{O} \\
\mathrm{Ca}(\mathrm{OH})_{2}+\mathrm{SiO}_{2}+\mathrm{H}_{2} \mathrm{O} \longrightarrow \mathrm{C}-\mathrm{S}-\mathrm{H}
\end{gathered}
$$

In the middle and late stages of hydration, the activity of $2 \mathrm{CaO} \cdot \mathrm{SiO}_{2}$ and $4 \mathrm{CaO} \cdot \mathrm{Al}_{2} \mathrm{O}_{3} \cdot \mathrm{Fe}_{2} \mathrm{O}_{3}$ is stimulated, and the following reactions occur:

$$
\begin{gathered}
2\left(2 \mathrm{CaO} \cdot \mathrm{SiO}_{2}\right)+9 \mathrm{H}_{2} \mathrm{O}=3 \mathrm{CaO} \cdot 2 \mathrm{SiO}_{2} \cdot 8 \mathrm{H}_{2} \mathrm{O}+\mathrm{Ca}(\mathrm{OH})_{2} \\
\mathrm{C}_{4} \mathrm{AF}+2 \mathrm{CH}+6 \mathrm{CaSO}_{4} \cdot 2 \mathrm{H}_{2} \mathrm{O}+50 \mathrm{H}=2 \mathrm{C}_{3}(\mathrm{~A}, \mathrm{~F}) \cdot 3 \mathrm{CaSO}_{4} \cdot 32 \mathrm{H}_{2} \mathrm{O}
\end{gathered}
$$

With the hydration process, XRD pattern (Figure 7), and SEM microstructure analysis (Figure 8), it can be found that some needle-shaped ettringite $\mathrm{Aft}$ (needle-stick-shaped AFt), block-shaped C-H gel (Block-shaped C-H) and sheet-shaped $\mathrm{C}-\mathrm{S}-\mathrm{H}$ gel (C-S-H gel flakes) formed after the paste reacted for 16 hours. These gels constitute the early strength skeleton of the backfill, which is the main reason why the paste has early strength.

\section{Experimental Research on Paste Pipeline Conveying}

5.1. Paste Proportioning and Pipeline Conveying Simulation System. To simulate the characteristics changes of coal mine paste in the pipeline conveying process, and thereby determining the stability and pumpability of the prepared paste, the experiment was carried out. The indoor paste proportioning and pipeline conveying simulation system in the Shandong University of Science and Technology was applied in this test. The system mainly includes two parts: the automatic paste proportioning system and the pipeline conveying system. And the system flow chart is shown in Figure 9.

5.1.1. The Paste Automatic Proportioning System. In the paste automatic proportioning system, three hoppers were used to hold aggregates like coal gangue and fly ash. These aggregates were weighed by an electronic belt scale and directly entered a mixing drum. At the same time, a hopper was used to hold 
TABLE 1: The chemical and mineral composition of the silicate cement.

\begin{tabular}{lccccccccc}
\hline \multirow{2}{*}{ Name } & \multicolumn{4}{c}{ Chemical composition/\% } & \multicolumn{4}{c}{ Main mineral composition/\% } \\
& $\mathrm{SiO}_{2}$ & $\mathrm{Al}_{2} \mathrm{O}_{3}$ & $\mathrm{Fe}_{2} \mathrm{O}_{3}$ & $\mathrm{CaO}$ & $\mathrm{SO}_{3}$ & $\mathrm{C}_{3} \mathrm{~S}$ & $\mathrm{C}_{2} \mathrm{~S}$ & $\mathrm{C}_{3} \mathrm{~A}$ & $\mathrm{C}_{4} \mathrm{AF}$ \\
\hline Silicate cement & 21.38 & 4.23 & 3.58 & 66.49 & 0.1 & 59.95 & 12.02 & 5.94 & 13.53 \\
\hline
\end{tabular}

TABle 2: The chemical composition of the gypsum.

\begin{tabular}{lcccccccr}
\hline \multirow{2}{*}{ Name } & & \multicolumn{3}{c}{ Chemical composition/\% } \\
& $\mathrm{CaO}$ & $\mathrm{Al}_{2} \mathrm{O}_{3}$ & $\mathrm{Fe}_{2} \mathrm{O}_{3}$ & $\mathrm{SO}_{3}$ & $\mathrm{SiO}_{2}$ & $\mathrm{MgO}$ & $\mathrm{Na}_{2} \mathrm{O}$ & Ignition loss \\
\hline Gypsum & 38.15 & 3.18 & 0.32 & 44.86 & 1.73 & 2.57 & 0.08 & 8.38 \\
\hline
\end{tabular}

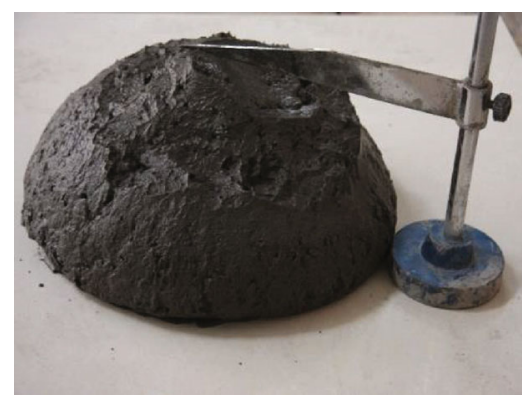

(a) Slump

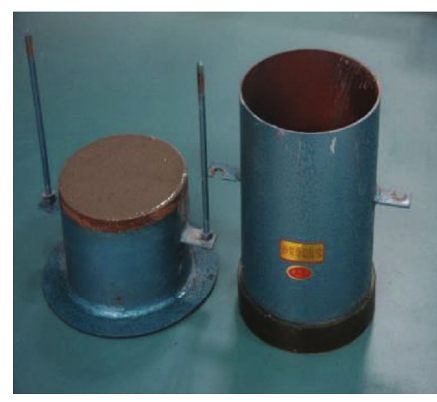

(b) Segregation degree

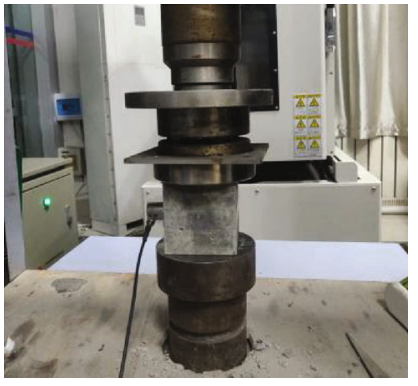

(c) Compressive strength

FIgURE 6: Measurement of test parameters.

TABLE 3: Results of the orthogonal test and paste parameter test.

\begin{tabular}{|c|c|c|c|c|c|c|c|c|c|c|c|c|}
\hline \multirow{2}{*}{ Test number } & \multirow{2}{*}{$\mathrm{A} / \%$} & \multirow{2}{*}{$\mathrm{B} / \%$} & \multirow{2}{*}{$\mathrm{C} / \%$} & \multirow{2}{*}{ Slump/cm } & \multirow{2}{*}{ Segregation degree $/ \mathrm{cm}$} & \multicolumn{2}{|c|}{$\begin{array}{l}\text { Setting } \\
\text { time/min }\end{array}$} & \multicolumn{5}{|c|}{ Compressive strength/MPa } \\
\hline & & & & & & Initial & Final & $16 \mathrm{~h}$ & $1 \mathrm{~d}$ & $3 \mathrm{~d}$ & $7 \mathrm{~d}$ & $28 \mathrm{~d}$ \\
\hline P1 & 1 & 0.2 & 79 & 26.4 & 2.2 & $4: 47$ & $5: 22$ & 0.04 & 0.22 & 0.89 & 1.48 & 2.58 \\
\hline P2 & 1 & 0.4 & 82 & 16.5 & 1.5 & $3: 38$ & $4: 24$ & 0.21 & 0.38 & 1.02 & 1.58 & 2.22 \\
\hline P3 & 1 & 0.6 & 85 & 13.1 & 0.6 & $3: 08$ & $3: 40$ & 0.32 & 0.53 & 1.56 & 1.69 & 2.05 \\
\hline P4 & 2 & 0.2 & 82 & 24.2 & 1.8 & $4: 10$ & $4: 50$ & 0.14 & 0.21 & 0.78 & 1.31 & 2.41 \\
\hline P5 & 2 & 0.4 & 85 & 15.8 & 0.7 & $3: 33$ & $3: 52$ & 0.28 & 0.68 & 1.20 & 1.61 & 1.98 \\
\hline P6 & 2 & 0.6 & 79 & 24.3 & 1.8 & $3: 51$ & $4: 30$ & 0.30 & 0.88 & 1.12 & 1.31 & 2.07 \\
\hline P7 & 3 & 0.2 & 85 & 17.4 & 0.8 & $3: 50$ & $4: 27$ & 0.06 & 0.21 & 0.98 & 1.24 & 2.46 \\
\hline P8 & 3 & 0.4 & 79 & 22.6 & 2.0 & $4: 18$ & $4: 41$ & 0.18 & 0.36 & 1.07 & 1.34 & 2.34 \\
\hline P9 & 3 & 0.6 & 82 & 19.4 & 1.4 & $3: 25$ & $4: 18$ & 0.24 & 0.48 & 1.36 & 1.68 & 2.03 \\
\hline
\end{tabular}

cementing materials. The cementing materials were continuously weighed by an impact flowmeter and entered another mixing drum. Water was weighed by an electromagnetic flowmeter and poured into the cementing material mixing drum. Finally, the mixed cement slurry was poured into the paste mixing drum and mixed evenly.

5.1.2. The Paste Pipeline Conveying System. In the paste pipeline conveying system, the mixed paste is first sent to the silo in front of the filling pump through the buffer hopper. The filling pump squeezes the paste from the silo to the pipeline. The paste reenters the buffer hopper after a cycle in the pipeline and then enters the silo of the filling pump again, which is the second cycle of pipeline conveying. The paste can circulate in the pipeline, which simulates the long-distance con- veying of the paste in the pipeline. During the simulation process, part of the paste can be taken out from the silo to measure its characteristics. And the density change of paste can be observed through the densimeter installed on the pipeline. After a long-distance conveying simulation, part of the paste is sent to the simulation stand to simulate the long-term strength characteristics in the goaf. The remaining paste is sent to the waste thick fluid pool for disposal.

\subsection{Paste Pipeline Conveying Test}

5.2.1. Preparation of the Paste. Before preparing the paste, the amount of various materials should be calculated according to the volume of the pipeline. The pipe used in the test had a diameter of $0.15 \mathrm{~m}$ and a length of $90 \mathrm{~m}$. The paste volume 


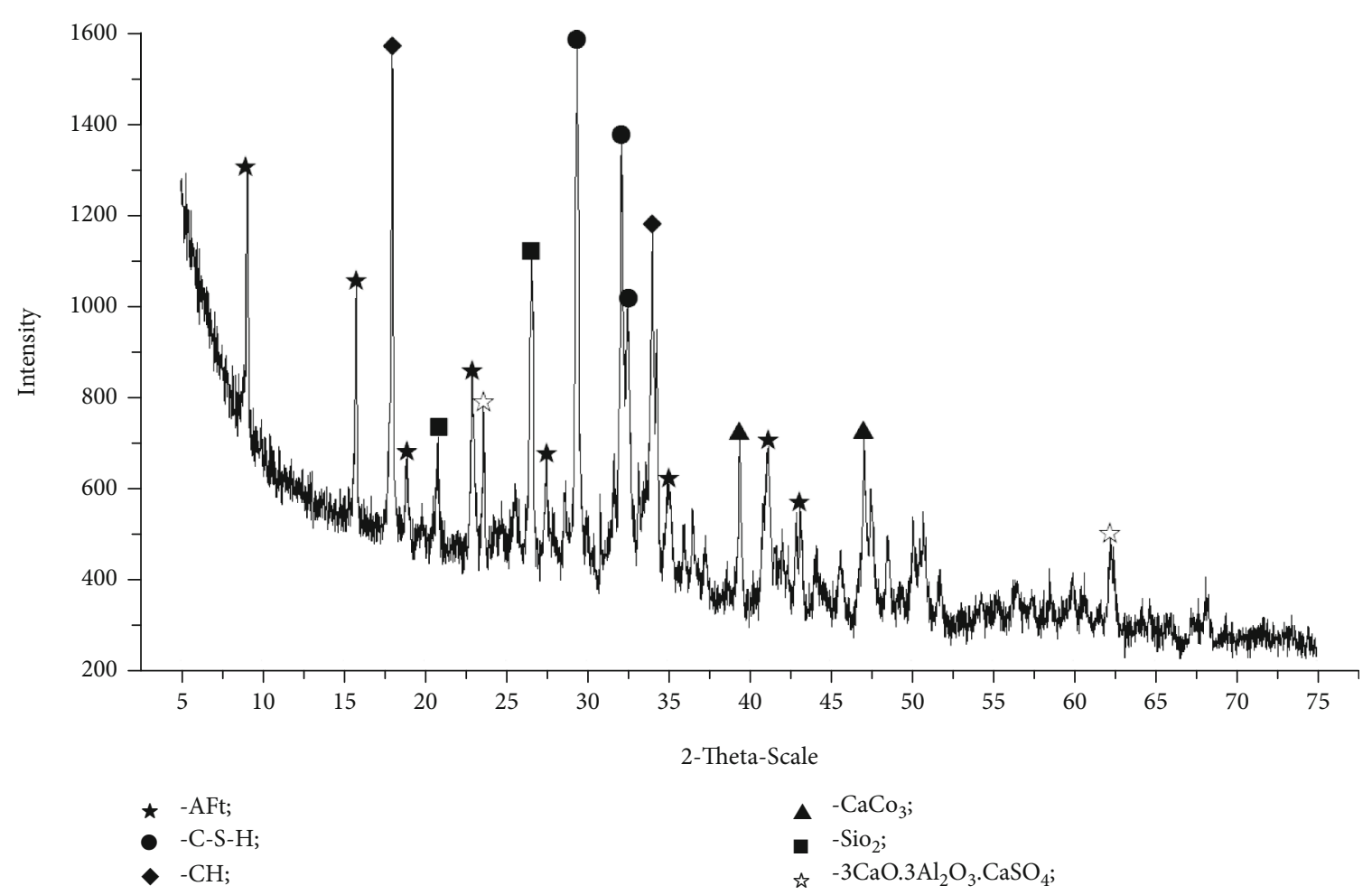

FIGURE 7: XRD pattern of 16-hour paste.
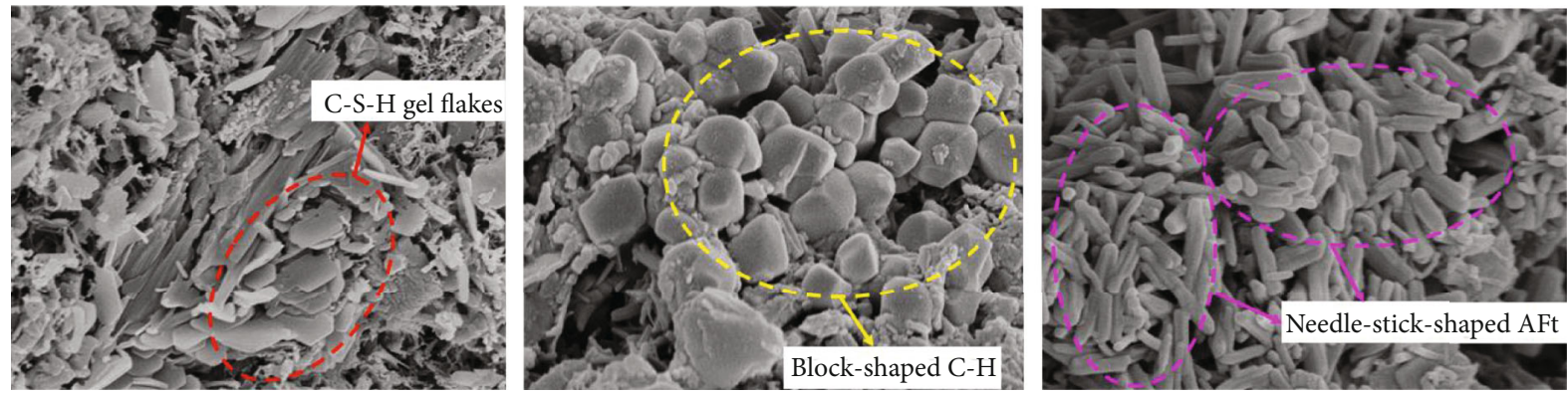

FIGURE 8: SEM pattern of 16-hour paste.

needed was $V=\pi \cdot r^{2} \cdot l=3.14 \times 0.075^{2} \times 90=1.59 \mathrm{~m}^{3}$. Considering that about $0.5 \mathrm{~m}^{3}$ paste should be kept in the pump truck during the pumping process, $2 \mathrm{~m}^{3}$ in volume of P9 paste was prepared for this test. With reference to the determined unit weight $\left(1720 \mathrm{~kg} / \mathrm{m}^{3}\right)$, the mass proportion of $\mathrm{P} 9$, the mass of coal gangue, fly ash, silicate cement, gypsum, sodium sulfate, and water in this test were calculated to be $1978.2 \mathrm{~kg}, 989.1 \mathrm{~kg}, 329.7 \mathrm{~kg}, 102.6 \mathrm{~kg}, 20.5 \mathrm{~kg}$, and $755.1 \mathrm{~kg}$, respectively.

The preparation process of the paste was as follows. First, some crushed coal gangue and fly ash were, respectively, transported to hopper 1 and hopper 2 in the paste system by a lifting crane. The silicate cement, gypsum, and sodium sulfate cementing materials that were mixed in accordance with the mass proportion were transported to the cementing hopper. Second, the proportion was set in the computer system which could automatically transport the weighed
$659.4 \mathrm{~kg}$ coal gangue and $329.7 \mathrm{~kg}$ fly ash directly to the paste mixing drum through a belt conveyor according to the proportion. Add water to the cementing hopper (with $109.9 \mathrm{~kg}$ silicate cement, $34.2 \mathrm{~kg}$ gypsum, $6.8 \mathrm{~kg}$ sodium sulfate, and $251.7 \mathrm{~kg}$ water) and stir for 1 minute. After the stirring, the cement slurry was discharged into the mixing drum. Finally, all materials were mixed in the paste mixing drum for 2 minutes, and the mixed paste were discharged to the silo at the front of the filling pump for pipeline conveying. The materials in the pipeline began to circulate, and the paste proportioning test was completed, as shown in Figure 10.

5.2.2. Study on Paste Pipeline Conveying. The mixed paste was then filled to the working face through the pipeline. In general, the distance from the ground filling station to the working surface is more than $2 \mathrm{~km}$, and the delivery time of the paste in the pipeline reaches $1 \sim 2 \mathrm{~h}$. Long delivery time 


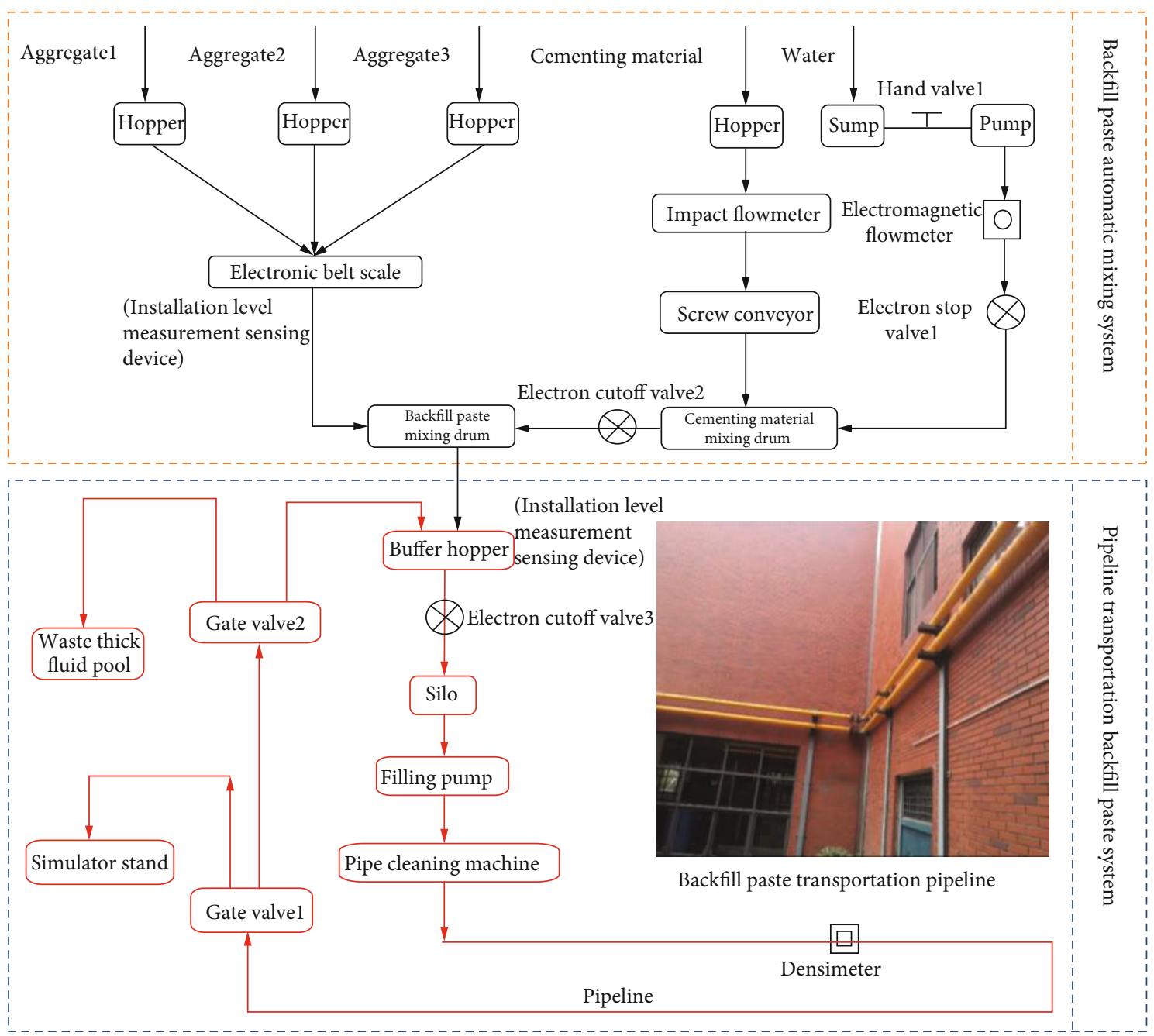

FIGURE 9: Paste proportioning and pipeline transportation simulation system.

will change the basic characteristics of the paste, so a pipeline delivery test is needed. The paste circulates in the pipeline to simulate the actual distance and transport time. In the test, the paste conveying speed was set as $0.5 \mathrm{~m} / \mathrm{s}$, and the conveying time as $2 \mathrm{~h}$. Samples were taken from the silo in front of the filling pump every $15 \mathrm{~min}$ to test the slump and segregation degree of the paste. Its density was directly read in the software.

Figure 11 shows the flow state of the paste in the pipeline. The paste basically moves in the way of full pipe and overall flat push, and no obvious precipitation or segregation is found in the pipeline conveying process. Therefore, it can be determined that the paste flows in the pipeline like a plunger.

During the pumping experiment, the authors measured and recorded the slump, segregation degree, and density of the paste in different periods and observed the changes. Before the paste entered the pipeline and after it circulated for 2 hours, some paste was put in a $70.7 \mathrm{~mm} \times 70.7 \mathrm{~mm} \times$ $70.7 \mathrm{~mm}$ test mold. When it could stand on its own, the mold was removed and the test block was placed in a standard curing box. After the paste was cured to the test age, its characteristics were measured. The influence of pipeline convey- ing on the paste is shown in Figure 12. The slump of the paste decreased gradually as the pumping time increased (see Figure 12(a)), from $19.4 \mathrm{~cm}$ at the beginning to $18.4 \mathrm{~cm}$ at the end. Experimental results have shown that although the slump of paste decreased after 2 hours of pipeline conveying, it still met the requirements of paste pumping. The segregation degree of the paste decreased with the pumping time increasing (see Figure 12(b)), from $1.4 \mathrm{~cm}$ to $0.7 \mathrm{~cm}$, but the reduction met the pumping requirements. The paste density improved gradually with the increase of pumping time (see Figure 12(c)). The initial change was small, and later it became larger. Since density refers to the mass concentration of the paste, the mass concentration gradually increased with pumping time getting longer. Figure 12(d) is the strength comparison of backfill transported by pipeline and without pipeline conveying. It can be seen that the strength of the backfill after pipeline conveying is slightly lower than that of the even-aged paste without pipeline conveying. Finally, the setting time of the paste before and after entering the pipeline was also measured. It was concluded that the initial setting time and final setting time of the paste transported through the pipeline extended slightly, but it did 


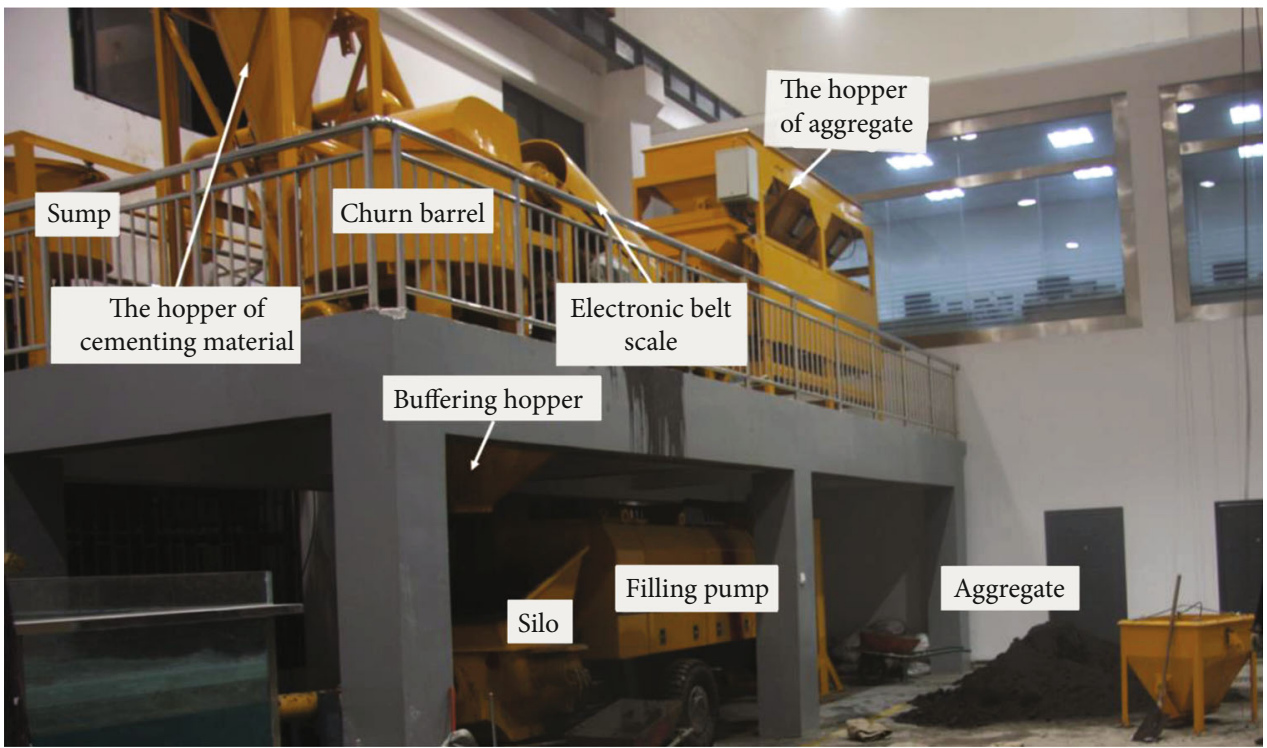

FIgURE 10: Paste proportioning and indoor test of pipeline transportation.

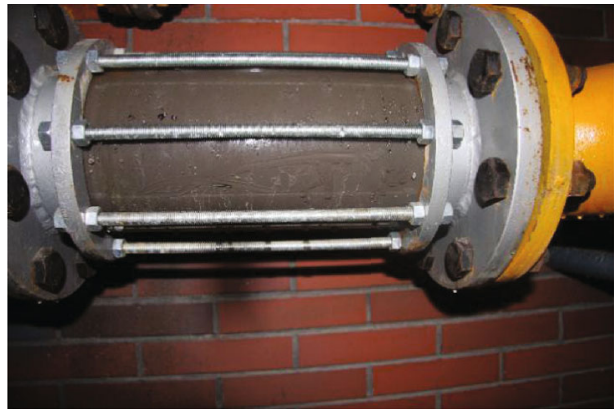

(a) $30 \mathrm{~m}$ from the filling pump

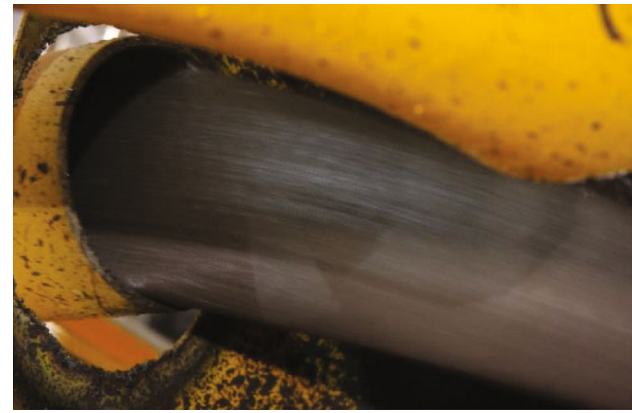

(b) Outlet

FIgUre 11: The flow state of the paste in the pipeline.

not affect the pipeline conveying of coal mine paste. By observing the paste flow pattern in the pipeline and the change of paste basic characteristics, P9 material can meet the requirements of paste pumping and backfill strength in the coal mine.

According to the analysis of the experimental results above, the basic characteristics of paste changes during the pumping process. The main reason is that a small amount of cementing material undergoes hydration reaction in the process, which leads to less free water in the paste, resulting in increasing mass concentration and decreasing slump and segregation. The main reason for the decline of backfill strength after pipeline conveying is the inner environment (temperature, humidity, etc.) of the pipeline.

\section{Conclusions}

(1) This paper obtained the requirements of the strength and pumpability parameters of coal mine paste filling. The paste strength ranges from $0.10 \sim 0.16 \mathrm{MPa}$ in the early stage and from $1.5 \sim 2.0 \mathrm{MPa}$ in the later stage. The conditions that the coal mine paste can be pumped are that the segregation degree is less than
$2 \mathrm{~cm}$, the slump is no less than $18 \mathrm{~cm}$, the initial setting time is $3 \sim 4 \mathrm{~h}$, the final setting time is $4 \sim 5 \mathrm{~h}$, the content of ultrafine particles with particle size less than $20 \mathrm{~m}$ in the paste is no less than $15 \%$, and the content of coal gangue with particle size less than $5 \mathrm{~mm}$ ranges from $35 \%$ to $45 \%$. The ratio of the maximum particle size of the aggregates to the diameter of the conveying pipe should be less than 1:5

(2) The range analysis of the test results shows that the mass concentration had the greatest influence on slump and segregation degree. Followed by calcium oxide, as an early strength agent, sodium sulfate had the greatest influence on the initial setting of the paste, the strength of 16-hour paste and 28-day paste. The optimal ratio of paste was determined according to the analysis. The microstructure of the paste was analyzed with XRD and SEM, and it was determined that ettringite $\mathrm{Aft}, \mathrm{CH}$ and $\mathrm{C}-\mathrm{S}-\mathrm{H}$ gels generated in the early stage of the paste provided the paste with early strength

(3) A pipeline conveying experiment was carried out for the optimal ratio $\mathrm{P} 9$. The results shows that the 


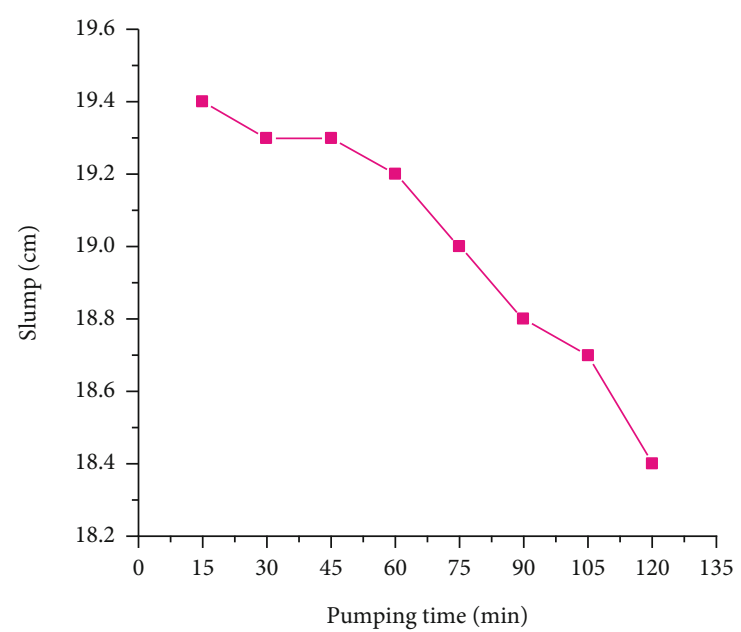

(a) Slump

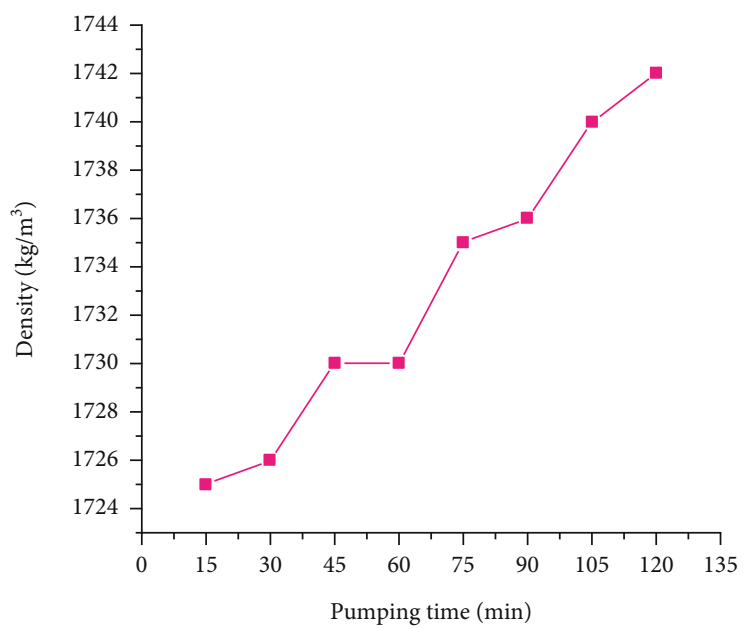

(c) Density

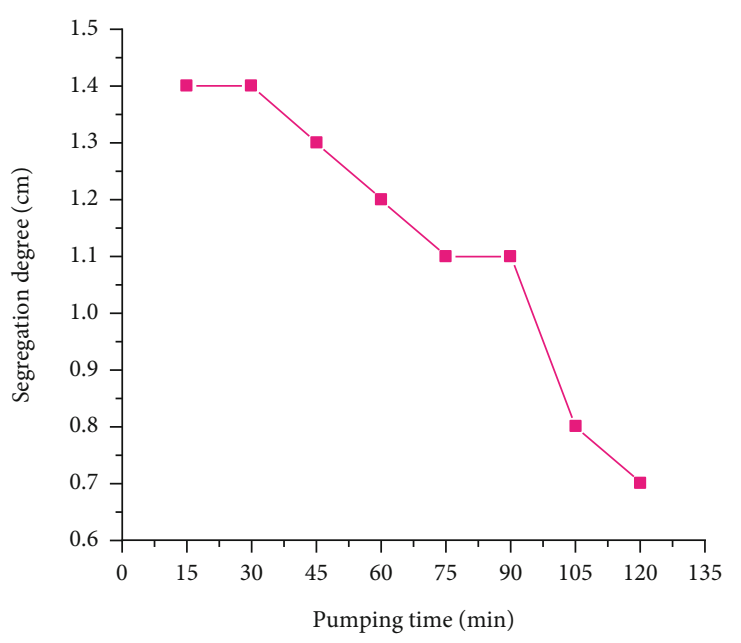

(b) Segregation degree

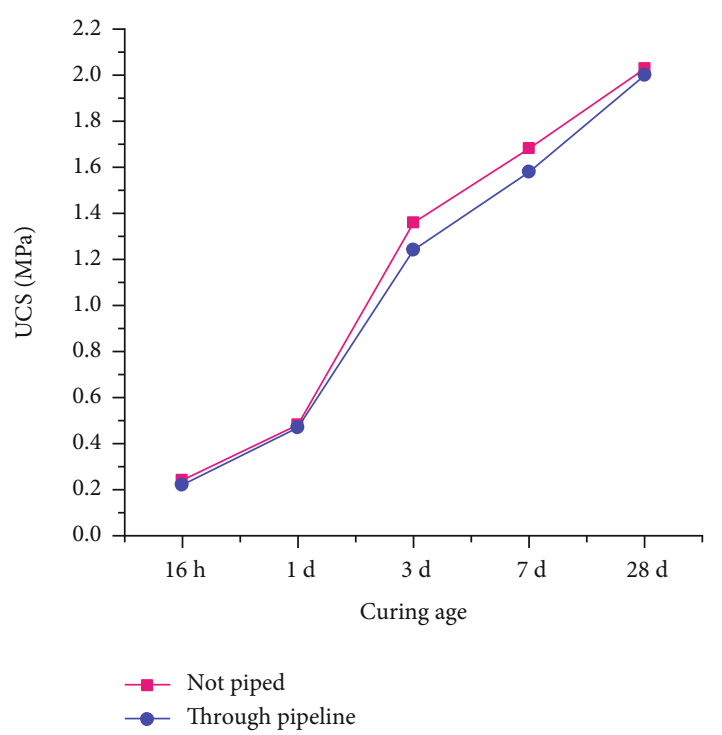

(d) Paste strength

FIgURE 12: The law of influence of pipeline transportation on paste characteristics.

slump and segregation decreased slightly, and the density increased as pumping time got longer. The initial setting time and final setting time of paste transported by pipeline slightly extended. The strength of backfill after pipeline conveying was slightly lower than that of paste without pipeline conveying at the same age. Although the parameters of paste changed after pumping, it still met the requirements of coal mine paste pumping and strength

(4) According to the analysis of the experimental results of pipeline conveying, the basic characteristics of paste changed in the process of pumping. The main reason is that hydration reaction occurs to some cementing material in the process of pumping, which results in the decline of free water in the paste, causing the increase of paste mass concentration and the decrease of slump and segregation. The main reason for the paste strength's decreases after pipeline conveying is the inner pipeline environment (temperature, humidity, etc.)

\section{Data Availability}

The data used to support the findings of this study are included within the article.

\section{Conflicts of Interest}

The authors declare that they have no conflict of interest.

\section{Acknowledgments}

This work was supported by the National Outstanding Youth Science Fund Project of National Natural Science Foundation of China $(\mathrm{CN}), 51704180$, research on bending failure mechanism of reinforced concrete-filled steel tubular support under uneven load, Jinxiao Liu (skd993938@sdust.edu.cn). 


\section{References}

[1] M. G. Qian, J. L. Xu, and X. X. Miao, "Green technique in coal mining," Journal of China University of Mining \& Technology, vol. 32, no. 4, pp. 343-348, 2003.

[2] M. G. Qian, "Research on green mining of coal resources in China: current status and future prospects," Journal of Mining \& Safety Engineering, vol. 26, no. 1, pp. 01-10, 2009.

[3] C. S. Bhanwar and S. Kumar, "Underground void filling by cemented mill tailings," International Journal of Mining Science and Technology, vol. 23, no. 11, pp. 893-900, 2013.

[4] H. Wu, G. Y. Zhao, Y. Chen, H. Y. Zhang, and J. C. Dai, “Deformation mechanism of un-cemented filling materials and grading effect in confined compaction tests," Journal of Mining \& Safety Engineering, vol. 35, no. 6, pp. 1225-1232, 2018.

[5] S. Cao and W. D. Song, "Effect of filling interval time on the mechanical strength and ultrasonic properties of cemented coarse tailing backfill," International Journal of Mineral Processing, vol. 166, no. 9, pp. 62-68, 2017.

[6] D. Y. Wei, C. F. Du, Y. F. Lin, and B. M. Chang, "Impact factors of hydration heat of cemented tailings backfill based on multi-index optimization," Case Studies in Thermal Engineering, vol. 16, no. 4, pp. 02-09, 2020.

[7] M. Benzaazoua, J. F. Fiset, B. Bussière, M. Villeneuve, and B. Plante, "Sludge recycling within cemented paste backfill: study of the mechanical and leachability properties," Minerals Engineering, vol. 19, no. 5, pp. 420-432, 2006.

[8] S. J. Yang, S. Su, and F. L. Wang, "Analysis of strength regularity of high concentration tailings cemented backfill," Bulletin of the Chinese Ceramic Society, vol. 40, no. 3, pp. 847-852, 2019.

[9] S. X. Yang and Y. H. Fu, "Study on evolution of damage on postpeak bearing stage of tailings filling body by cementsand ratio," Industrial Minerals \& Processing, vol. 47, no. 4, pp. 26-28, 2018.

[10] J. Li and F. Deng, "Experimental study on long-term strength of full tailings cemented backfill," Industrial Minerals \& Processing, vol. 47, no. 10, pp. 47-49, 2018.

[11] W. P. Liu, Y. Z. Rao, W. F. Xu, X. M. Hong, Z. J. Liu, and M. Han, "Effect of acidic corrosion on physical and mechanical properties of full tailings cemented backfill," Mining Research and Development, vol. 38, no. 3, pp. 91-94, 2018.

[12] W. Yang, Q. L. Zhang, S. Yang, and X. M. Wang, "Mechanical property of high concentration total tailing cemented backfilling under dynamic loading," Journal of Central South University (Science and Technology), vol. 48, no. 1, pp. 156-161, 2017.

[13] B. Yang, S. J. Yang, and F. L. Wang, "Numerical simulation of cemented filling pipeline transportation of high-density whole tailing based on ANSYS/FLOTRAN," Gold Science \& Technology, vol. 28, no. 5, pp. 60-65, 2015.

[14] C. J. Chen and S. J. Cai, "Issues related to the pilot operation of paste filling system in Jingchuan's No.2 mining district," Mining Research and Development, vol. 21, no. 3, pp. 21-23, 2001.

[15] X. Feng, S. R. Cao, Y. L. Zhuo, Y. X. Li, J. W. Han, and X. J. Wang, "Destructive tests on the cemented rock filling body under different stress paths," Mining Research and Development, vol. 36, no. 7, pp. 43-46, 2016.

[16] J. F. Zhang, K. Wang, X. Q. Zhang, J. B. Yan, and Y. Zheng, "Analysis on creep characteristics of paste filling materials in residual roadway support," Mining Research and Development, vol. 38, no. 3, pp. 95-99, 2018.
[17] J. H. Liu, J. S. Li, and G. M. Wang, "Simulation study on the paste pumping system with dual-pump parallel based on AMESim," Mining Research and Development, vol. 37, no. 11, pp. 86-89, 2017.

[18] H. E. Gui-Cheng, L. I. Yong, D. I. De-Xin, and Z. H. Zhi-Jun, "Strength characteristic of cemented waste rock backfills and its application," Journal of Mining \& Safety Engineering, vol. S1, pp. 74-79, 2013.

[19] S. Lu and X. P. Wang, "Study on the influence of rock block proportion and shape on the mechanical properties of cemented filling body," Mining Research and Development, vol. 38, no. 3, pp. 73-76, 2018.

[20] H. G. Ren, H. J. Wang, and M. L. Li, "Technical study on stripty peand pre-support mining method with subsequent cemented rock fill," Industrial Minerals \& Processing, vol. 46, no. 1, pp. 64-67, 2017.

[21] X. Feng, Y. L. Zhuo, C. Chen, J. W. Han, X. J. Wang, and Y. Hu, "Study on mechanical properties and acoustic emission characteristics of cemented filling body," Industrial Minerals \& Processing, vol. 45, no. 9, pp. 44-47, 2016.

[22] X. J. Wang, Y. L. Zhuo, C. Chen, J. W. Han, X. Feng, and Y. Hu, "Study on the main harmful material under failure process of blocky rock cemented filling body," Mining Research and Development, vol. 36, no. 2, pp. 43-47, 2016.

[23] H. J. Wang, "The characterization of activated calcium carbonate with the rate of suspension in water," Industrial Minerals \& Processing, vol. 12, no. 4, pp. 16-18, 2000.

[24] H. Y. He, T. F. Huang, and Y. H. Xu, “An experimental study on technology of cemented flling with high-water quick consolidating tailings and its operation in fankou lead-zinc mine," Mining Research and Development, vol. 16, no. 12, pp. 16-20, 1996.

[25] G. B. Ding and C. T. Li, "Experiment on high-water quick consolidated filling with single piping unclassified tailings in fenghuangshan copper mine," Mining Research and Development, vol. 16, no. 12, pp. 90-92, 1996.

[26] Y. L. Zhou, C. Xu, X. Y. Wang, Y. D. Dou, Z. G. Huan, and J. Chang, "Fast setting tricalcium silicate/magnesium phosphate premixed cement for root canal filling," Ceramics International, vol. 44, no. 3, pp. 3015-3023, 2018.

[27] Y.-H. Ham, D.-P. Kim, K.-S. Park et al., "Dual etch processes of via and metal paste filling for through silicon via process," Thin Solid Films, vol. 519, no. 8, pp. 6727-6731, 2011.

[28] X. S. Zhou, Z. L. Yang, and P. Han, "Innovation design of long-distance pipelines buried under high-filling planned roads," Natural Gas Industry B, vol. 2, no. 2-3, pp. 198202, 2015.

[29] W. B. Zhu, J. M. Xu, J. L. Xu, D. Y. Chen, and J. X. Shi, "Piercolumn backfill mining technology for controlling surface subsidence," International Journal of Rock Mechanics \& Mining Sciences, vol. 96, no. 7, pp. 58-65, 2017.

[30] B. Carolina and P. Axel, "The future of underground spatial planning and the resulting potential risks from the point of view of mining subsidence engineering," International Journal of Mining Science and Technology, vol. 30, no. 1, pp. 93-98, 2020.

[31] G. L. Guo, X. J. Zhu, J. F. Zha, and Q. Wang, "Subsidence prediction method based on equivalent mining height theory for solid backfilling mining," Transactions of the Nonferrous Metals Society of China, vol. 24, no. 10, pp. 3302-3308, 2014. 
[32] L. S. Xie, "Development of cemented backfilling technology in mines," Changsha Research Institute of Mine, vol. 19, pp. 0105, 2003.

[33] L. G. Li, Z. Y. Zhuo, J. Zhu, J. J. Chen, and A. K. H. Kwan, "Reutilizing ceramic polishing waste as powder filler in mortar to reduce cement content by $33 \%$ and increase strength by 85\%," Powder Technology, vol. 355, no. 10, pp. 119-126, 2019.

[34] S. H. Yin, Y. J. Shao, A. X. Wu, H. J. Wang, X. H. Liu, and Y. Wang, "A systematic review of paste technology in metal mines for cleaner production in China," Journal of Cleaner Production, vol. 247, no. 2, pp. 119-590, 2020.

[35] Q. Li and Y. Peng, "Research and prospect on mine filling technique," Morden Mining, vol. 495, pp. 8-13, 2010.

[36] S. J. Chen, Z. W. Du, Z. Zhang, D. W. Yin, F. Feng, and J. B. $\mathrm{Ma}$, "Effects of red mud additions on gangue-cemented paste backfill properties," Powder Technology, vol. 367, no. 5, pp. 833-840, 2020.

[37] L. Liu, J. Xin, C. C. Qi, H. L. Jia, and K. I. Song, "Experimental investigation of mechanical, hydration, microstructure and electrical properties of cemented paste backfill," Construction and Building Materials, vol. 263, no. 12, pp. 120-137, 2020.

[38] M. Vasumithran, K. B. Anand, and D. Sathyan, "Effects of fillers on the properties of cement grouts," Construction and Building Materials, vol. 246, no. 6, pp. 118-128, 2020.

[39] J. Wang, J. X. Fu, W. D. Song, Y. F. Zhang, and Y. Wang, "Mechanical behavior, acoustic emission properties and damage evolution of cemented paste backfill considering structural feature," Construction and Building Materials, vol. 261, no. 11, pp. 119-128, 2020.

[40] J. Y. Wu, H. W. Jing, Q. Yin, B. Meng, and G. S. Han, "Strength and ultrasonic properties of cemented waste rock backfill considering confining pressure, dosage and particle size effects," Construction and Building Materials, vol. 242, no. 5, pp. 118132, 2020.

[41] M. Chen, P. H. Wen, C. H. Wang, Z. Chai, and Z. W. Gao, "Evaluation of particle size distribution and mechanical properties of mineral waste slag as filling material," Construction and Building Materials, vol. 253, no. 8, pp. 119132, 2020.

[42] Y. N. Bo, T. H. Kang, J. T. Kang, Y. J. Chena, L. L. Wu, and M. Z. Du, "Investigation of the hydration kinetics and microstructure formation mechanism of fresh fly ash cemented filling materials based on hydration heat and volume resistivity characteristics," Applied Clay Science, vol. 166, no. 12, pp. 146-158, 2018.

[43] J. Camilleri, A. Cutajar, and B. Mallia, "Hydration characteristics of zirconium oxide replaced Portland cement for use as a root-end filling material," Dental Materials, vol. 27, no. 8, pp. 845-854, 2011.

[44] O. Bahadir, S. Talha, T. Tugrul, and Y. Abdulazim, “Geotechnical properties of recycled construction and demolition materials for filling applications," Transportation Geotechnics, vol. 24, no. 9, pp. 100-380, 2020.

[45] M. Fall and M. Benzaazoua, "Modeling the effect of sulphate on strength development of paste backfill and binder mixture optimization," Cement and Concrete Research, vol. 35, no. 2, pp. 301-314, 2005.

[46] T. Jonathan and J. D. Kenneth, "MacKenzie structure and mechanical properties of aluminosilicate geopolymer composites with Portland cement and its constituent minerals," Cement and Concrete Research, vol. 40, pp. 787-794, 2010.
[47] A. A. Samuel, B. Leon, S. Jan, B. H. Mohsen, and Z. Maciej, "Effect of sulfate additions on hydration and performance of ternary slag-limestone composite cements," Construction and Building Materials, vol. 164, no. 3, pp. 451-462, 2018.

[48] Z. Prošek, V. Nežerka, R. Hlůžek, J. Trejbal, P. Tesárek, and G. Karra'a, "Role of lime, fly ash, and slag in cement pastes containing recycled concrete fines," Construction and Building Materials, vol. 201, no. 3, pp. 702-714, 2019.

[49] A. A. Ramezanianpour, E. Ghiasvand, and I. Nickseresht, "Influence of various amounts of limestone powder on performance of Portland limestone cement concretes," Cement \& Concrete Composites, vol. 31, no. 10, pp. 715-720, 2009.

[50] K. D. Weerdt, K. O. Kjellsen, E. Sellevold, and H. Justnes, "Synergy between fly ash and limestone powder in ternary cements," Cement \& Concrete Composites, vol. 33, no. 1, pp. 30-38, 2011.

[51] E. F. Irassar, D. Violin, V. F. Rahhal, C. Milanes, M. A. Trezza, and V. L. Bonavetti, "Influence of limestone content, gypsum content and fineness on early age properties of Portland limestone cement produced by inter-grinding," Cement \& Concrete Composites, vol. 33, no. 2, pp. 192-200, 2011.

[52] V. Kirk, A. Matthew, O. Tandre, S. Gaurav, and N. Narayanan, "Hydration and strength development in ternary Portland cement blends containing limestone and fly ash or metakaolin," Cement \& Concrete Composites, vol. 39, no. 5, pp. 93-103, 2013.

[53] A. Kumar, T. Oey, S. Kim et al., "Simple methods to estimate the influence of limestone fillers on reaction and property evolution in cementitious materials," Cement \& Concrete Composites, vol. 42, no. 9, pp. 20-29, 2013.

[54] W. C. Li, "Strength and self-desiccation of slag-cemented paste backfill at early ages: link to initial sulphate concentration," Cement \& Concrete Composites, vol. 89, no. 5, pp. 160-168, 2018.

[55] F. Mamadou and P. Mukesh, "Coupled effects of sulphate and temperature on the strength development of cemented tailings backfills: Portland cement-paste backfill," Cement \& Concrete Composites, vol. 32, pp. 819-828, 2010.

[56] S. Salman and J. Jeong Gook, "Assessment of molybdenum mine tailings as filler in cement mortar," Journal of Building Engineering, vol. 31, no. 9, pp. 101-322, 2020.

[57] C. Z. Li and L. H. Jiang, "Utilization of limestone powder as an activator for early-age strength improvement of slag concrete," Construction and Building Materials, vol. 253, no. 8, pp. 119257, 2020.

[58] S. F. A. Shah, B. Chen, S. Y. Oderji, M. A. Haque, and M. R. Ahmad, "Improvement of early strength of fly ash-slag based one-part alkali activated mortar," Construction and Building Materials, vol. 246, no. 6, pp. 118-533, 2020.

[59] P. Lu, "A few points about the mechanics of back filling which restrain the development of cementing back filling method," Gold, vol. 15, pp. 18-22, 1994.

[60] H. H. Sun, Contemporary Cemented Filling Technology, Metallurgical Industry Press, China, 2002.

[61] S. J. Cai, Mechanical Foundation of Mine Filling, Metallurgical Industry Press, China, 2009.

[62] P. Liu, "Experiental study on stress and strain characteristic of gangue filling material," Mining Safety \& Environmental Protection, vol. 46, no. 4, pp. 13-16, 2019.

[63] B. N. Hu and A. G. Guo, "Testing study on coal waste back filling material compression simulation," Journal of China Coal Society, vol. 34, no. 8, pp. 1076-1080, 2009. 
[64] C. Q. Zhu, Z. Zhou, Q. F. Li, Y. E. Shi, and Y. Ou, "Experimental study on the compression properties of gangue," Mining Safety \& Environmental Protection, vol. 30, no. 4, pp. 1-6, 2015.

[65] D. N. Zhang, "Experimental study of compression properties of gangue filling material with different size distribution," Coal Mining Technology, vol. 21, no. 6, pp. 15-17, 2016. 